
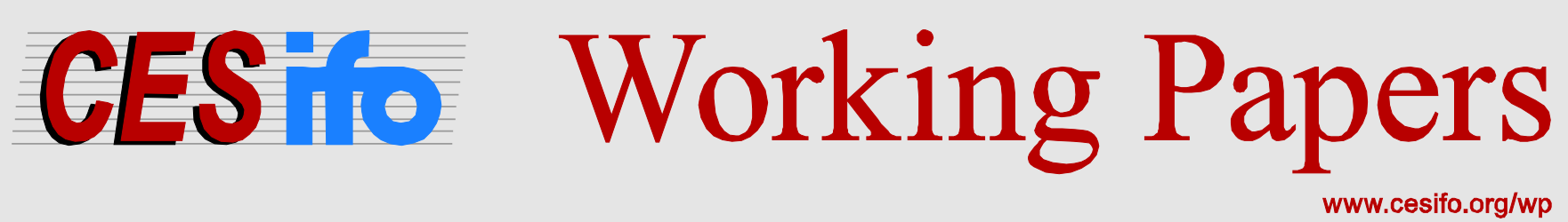

\title{
Input Trade Liberalisation and Wage-inequality with Non-traded Goods
}

\author{
Soumyatanu Mukherjee
}

CESIFO WORKING PAPER NO. 5472

CATEgORY 8: TRADE POLICY

August 2015

An electronic version of the paper may be downloaded

- from the SSRN website: Www.SSRN.com

- from the RePEc website: Www.RePEc.org

- from the CESifo website: www.CESifo-group.org/wp 


\title{
Input Trade Liberalisation and Wage-inequality with Non-traded Goods
}

\begin{abstract}
This paper develops a multi-sector full-employment general equilibrium model for a typical developing country (DC hereafter) like India with internationally non-traded goods and international fragmentation in skill-intensive production, to explore the general equilibrium impact of such trade-induced growth in the skill-intensive sector on informal sector wages and employment and most importantly, how this impact is mediated through the existence of finished non-tradable and the corresponding domestic demand-supply forces. The economy is also characterised by dual unskilled labour market with unionized formal and non-unionised informal sectors, consistent with the empirical literature on India. The idea is to judge theoretically how far the growth in the skill-intensive sector due to the tariff-reduction on the imported inputs in the skill-intensive production has contributed to the movement in informal unskilled wage and consequently to the direction of relative wage-gap. Numerical analysis has also been performed to simulate how the changes in elasticities of factor substitution in production in different sectors account for the movement in informal wage and therefore the movement in skilled-unskilled wage gap. This paper challenges the view that the relative wageinequality in a DC like India with rigid organised sector labour market has unequivocally been governed only by the increase in the skilled wages.
\end{abstract}

JEL-Code: F130, J310.

Keywords: input trade liberalisation, non-traded goods, informal wage, wage-inequality.

Soumyatanu Mukherjee

School of Economics, CREDIT \& GEP

University of Nottingham / UK

Soumyatanu.Mukherjee@nottingham.ac.uk 


\section{Introduction}

The idea that trade liberalization could be the reason for the rising skill premium documented in many developing countries (DCs) is often dismissed from the perspective of the Stolper-Samuelson (SS hereafter) theorem. Let us assume that in a two country, two commodity framework the home country (a small, open developing economy) exports good $X$, that is, it has a comparative advantage in good $X$, indicated by the lower relative price of good $X$. Whatever may be the reason of such comparative advantage or price differences, through arbitrage (buying cheap and selling dear) and consequent physical movements of goods across national borders, the domestic prices (net of trade costs) will eventually be equalised when demand and supply are equated. Therefore, the relative price of good $X$ rises in the home country and falls in the foreign country. Let us also assume that the home exportable goods are relatively unskilled labour-intensive. As the relative price of exportables increases, the production of the import-competing good $Y$ contracts and that of the exportable good $X$ increases. The consequent resource reallocation leads to an excess demand for unskilled labour and an excess supply of skilled labour because the expanding $X$ sector requires more unskilled labour and can absorb fewer skilled labourers than are released by the contracting $Y$ sector. Hence, the unskilled money wage increases whereas the skilled money wage declines. However, we can expect something more than just these changes in the absolute prices. An appeal to the SS theorem indicates that free trade leads the real wage to increase and the real return to capital falls (Caves et al., 2004). Therefore, in the home country, unskilled workers gain through trade.

However, in practice, the welfare implication of trade liberalisation on the poor unskilled workers is ambiguous. This is because, as pointed out by Sharma and Morrissey (2006), in order to be competitive in the world market, the exportable producers in developing countries often seek efficient and relatively high skilled labour. The poor households capable of supplying most unskilled labour cannot get direct benefit from trade liberalisation or global integration of a particular sector. The benefit, if any, tends to be indirect, through 
backward linkages in production and consequent demand. To establish this theoretically one needs to explore an appropriate general equilibrium model that matches with the empirical regularity and considers explicitly all associated aspects in organisation of production and factor distribution issues for the particular type of economy under consideration.

One problem is labour-market rigidity as observed typically in the formal industrial sectors of India (Topalova, 2010; Besley and Burgess, 2004) that hinders free mobility of unskilled and skilled labourers across sectors. Robbins (1996), Sanchez-Paramo and Schady (2003), Attanasio, Goldberg, Pavcnik (2004) on DCs like Argentina, Brazil, Mexico, Chile and Colombia, and Topalova (2010) for Indian districts, provide grounds for the proponents of specific-factor model of Ron Jones (1971) by concluding that the skilled labour-intensive sectors do not substitute away skilled labour for the unskilled labour. In the specific factor model of trade where the number of factors of production is greater than the number of traded goods, the endowment base of the economy has direct influence on wages. It may appear obvious then to presuppose better applicability of such a model on the basis of the findings of Robbins (1996) for Columbia of strong domestic supply impact on relative wages. But the specific factor model too, unless modified, cannot explain the symmetric changes in the wage gap in the trading nations.

Along with this, one should never neglect the role of the informal sector, which is the unregulated part of the economy where minimum wage laws and labour regulations are either totally absent or weakly implemented. Since DCs are generally deficient in effective employment insurance schemes, the displaced workers from the sector experiencing decline in relative price can hardly afford to remain unemployed. Absorption of labour retrenched from the more regulated sectors by this sector is, therefore, likely to be a major reason behind the concurrent increase in inequality and informalisation, as well as the relatively jobless patterns of growth observed in many DCs in the recent years, including India (Razmi, 2009). The share of the informal sector in total employment is typically quite high in DCs (Razmi, 2009). Agenor (1996) cites an average figure of more than $70 \%$ for DCs. The share of the informal sector 
in total output can also be quite high. For example, Nagaraj (2004) reports a figure of $40 \%$ for India. Unfortunately, most of the relevant literature in this context has neglected the special nature of the informal sector in developing countries' labour markets.

As already documented in Chapter 2, existence of the internationally nontraded goods with the domestic market clearing condition, significantly changes many standard results of the trade theory models. Since most of the non-traded production in the DCs like India uses unskilled labour intensively, any discussion of widening wage gap in the unskilled labour-abundant developing countries like India through trade liberalisation cannot be complete without such non-traded goods being taken into account.

The main problem with these standard theories is their failure to capture the diverse trade pattern that the developing nations exhibit in their export baskets recently and the institutional characteristics specific to them. Peculiarities such as exporting both skill-intensive manufacturing and unskilled labour intensive agricultural products, coexistence of organised and informal labour markets and the production of internationally non-tradable, are capable of explaining the relationship between openness and wage-gap in the DCs like India.

In 1991, after decades of pursuing an import-substitution industrialization strategy, India introduced a radical reform of her external sector. As reported in Kumar and Mishra (2008), the average tariff imposed on manufacturing products dropped from 117 per cent in 1990-91 to 39 per cent in 1999-2000. The reduction in tariffs was much more severe in India than in the trade liberalization experiences in Latin American countries such as Mexico, Colombia and Brazil (Kumar and Mishra, 2008). In addition to tariffs, India has also reduced non-tariff barriers (NTBs) from 1991. The average 'importcoverage ratio' (the share of imports subject to non-tariff barriers) reduced from 82 per cent in 1990-91 to 17 per cent in 1999-2000 (Kumar and Mishra, 2008). As defined in Feenstra and Hanson (1996), Jones and Kierzkowski (2001) and others, a sharp decline in transportation and communication costs during liberalisation makes it easier for the DCs to specialise in part of the production chain and outsource other parts of the production process to 
countries where factor prices and intensities are appropriate for that particular fragment. This gives birth to the input trade where this particular input gets exchanged in the world market for another exportable input produced in the home country. Das (2012) found that in developing countries such as India, China, South-East Asia and Latin America higher percentage of trade has been attributed to production-sharing in hi-technology products, service(s) and capital goods. As found in Goldberg et al. (2009), trade liberalisation in India also involves reduction in barriers to trade on imported inputs and thereby providing access to more and newer varieties of cheaper inputs from the other countries. Goldberg et al. (2010) estimated that input tariffs declined on average by 24 percentage points during 1989-1997. Arora and Chakrabarti (2004) provide empirical evidence of the significant impact of outsourcing of skill-intensive production on widening skilled-unskilled wage gap in Indian context. Therefore, an important agenda of research becomes to examine the implications of input trade liberalisation on wage-inequality, stepping out of the standard $2 \times 2 \mathrm{HO}$ structure, using a more convincing and encompassing theoretical structure that incorporates all these specific features mentioned above relevant for a small, open developing dual economy like India.

Liberalised economic policies generally shift resources away from the nontraded sectors to the traded sectors of the economy. Since the non-traded production by definition must match its domestic demand, trade liberalisation induced expansion of activities in the traded sectors will be possible only through a fall in the demand for non-tradeables. Therefore, as pointed out by Marjit and Acharyya (2000, 2003) whether non-traded production is organised in the informal or in the formal sector ${ }^{1}$ should be crucial to determine the impact on wage-inequality. Typically, the formal non-traded sector produces internationally non-tradable including all public services, hotel accommodation, real estate, construction, hair-cut and commodities produced to meet special customs or conditions of the country. Similarly, the nontradable produced in the unorganised informal sectors include items such as

\footnotetext{
${ }^{1}$ Typically we shall confine ourselves in this paper characterising the informal sector as the sector with unorganised unskilled labour market in line with other theoretical papers such as Marjit and Acharyya (2000, 2003), Chaudhuri (2005), Chaudhuri and Banerjee (2010) and so on.
} 
small domestic industries, services provided by petty traders or street-side vendors and so on. If the non-tradable is produced in a formal sector with unionised wage, the non-traded price may be determined solely by the cost of production independent of the demand for non-tradable. In such a case demand variation consequent upon trade liberalization induced real income changes alters only the non-traded production. Accordingly any change in the wagegap is triggered by the consequent resource reallocation across the non-traded and traded sectors. But if the non-traded sector is an informal sector, variations in the demand for non-tradable are followed by the changes in both production and price of the non-tradable. Accordingly, trade liberalization will have quite different implications on the wage-gap between skilled and unskilled workers.

The importance of non-traded goods in theoretical models determining the direction of skilled-unskilled wage gap has been documented by Marjit and Acharyya (2000, 2003), Chaudhuri and Yabuuchi (2008) who have used a four-sector general equilibrium model to study the consequences of import liberalization on skilled-unskilled wage gap, highlighting the significance of dualism in labour market and role of non-tradable commodities in driving the results. Gupta and Dutta (2011) incorporated involuntary unemployment of both skilled and unskilled labour in a three-sector model with non-traded goods to understand the implications of trade liberalisation-induced changes on skilled-unskilled relative wage and on the unemployment rates. This paper contributes to this research arena by sketching out the implication of input trade liberalisation on wage-inequality with dual labour market, large informal sector and non-traded goods. The purpose of such a comparative static exercise is two-fold. Firstly, the accelerated growth in Indian manufacturing and service sectors has largely been attributed to dramatic reduction in tariffs and NTBs on the imports of intermediate inputs as emanates from recent empirical evidence (Goldberg et al., 2009; 2010). Secondly, the recent empirical literature (Panagariya, 2004; Kotwal et al., 2011) suggests that the skill-intensive manufacturing and service industries such as communication services, financial services and business services in India experienced significant growth in exports during the liberalised regime, where software accounted for the highest share of all service exports, at least up to the recent financial crisis 
(Kotwal et al., 2011). Dehejia and Panagariya (2010) argued that imports of capital-intensive foreign inputs (embodying foreign technology) by the skillintensive service sectors (primarily software services and IT-enabled services) facilitated the growth of these sectors in India in the post-reform period. At the same instance, Hasan (2002) provided evidence from panel data on Indian manufacturing firms in favour of a significant effect of imported technology on productivity. Hence, access to newer varieties of foreign inputs owing to trade reform has fuelled such growth in India's service industries during the liberalised regime. Therefore, there should be an increased demand for skilled labour, due to the increase in demand by the skill-intensive service industries both at the extensive margin and due to the skill-biased technological change at the intensive margin owing to the increased skill content of imported inputs that are then assembled for export. Therefore, the contribution of this paper is to adopt a tractable but encompassing general equilibrium structure to trace out the implications of such productivity surges in the skill-intensive service sector, brought about by the tariff reform on the imports of capital-intensive inputs, on the non-traded sector and subsequently on the unskilled labour market and informal unskilled wage.

The general equilibrium framework used in this paper follows the available empirical evidence that low-skilled workers cannot afford to remain unemployed and the retrenched unskilled workers from the organised formal sectors get absorbed in the unorganised informal sectors at market-determined lower wages. Our modelling approach, closely follow Marjit and Acharyya (2003) with organised (formal) and unorganised (informal) non-traded sectors respectively to enlighten the role of non-tradable in determining the implications on unskilled informal wage and consequently on the relative wage-gap. The framework used in this paper can be viewed as a generalisation of Marjit et al. (2007) with additions of skill-intensive sector and non-traded final good producing sector. 


\section{The Model}

\subsection{Non-traded Production in Formal Sector with Contractual Money Wages}

Let us consider a small, open dual economy comprising of four sectors. Sector $A$ is the rural agricultural sector (with informal or unorganised labour market for the unskilled labourers) producing a tradable agricultural good using unskilled labour $(L)$ and land-capital $(T)^{2}$ Sector $U$ is an unskilled labourintensive formal manufacturing sector (with organised labour market for unskilled workers) in the urban area, producing with unskilled labour, capital $(K)$ and an internationally non-traded intermediate input ${ }^{3}$, which is, in turn, produced in one segment of the formal sector $U$ (sub-sector $I$ ) using unionised unskilled workers and capital. The skill-intensive manufacturing sector $(S)$ uses skilled labour $\left(L_{S}\right)$, capital and a hi-technology-intensive imported intermediate input produced abroad $(M)^{4}$. Consistent with empirical evidence ${ }^{5}$ we assume that only the relatively skill-intensive firms use imported intermediate inputs and consequently pay for foreign technology licences or foreign technical assistance. Furthermore, there is an advalorem tariff $(t)$ imposed on the import of $M .{ }^{6}$

\footnotetext{
${ }^{2}$ The input 'land-capital' broadly includes land and other durable assets. See Bardhan (1972), Chaudhuri (2007) and Mukherjee (2012) in this context.

${ }^{3}$ Examples of such non-traded intermediate input include electricity, water supply, local transportation, goods with very high transportation costs such as gravel and so on.

${ }^{4}$ Examples of such imported inputs include computer data storage units, automatic data processing machines and so on.

${ }^{5}$ See for example Alvarez and Lopez (2005), Lopez (2008, 2015) and so on.

${ }^{6}$ This should be interpreted here as the advalorem equivalence of tariff and non-tariff barriers (NTBs).
} 
Figure 1: The Model Structure

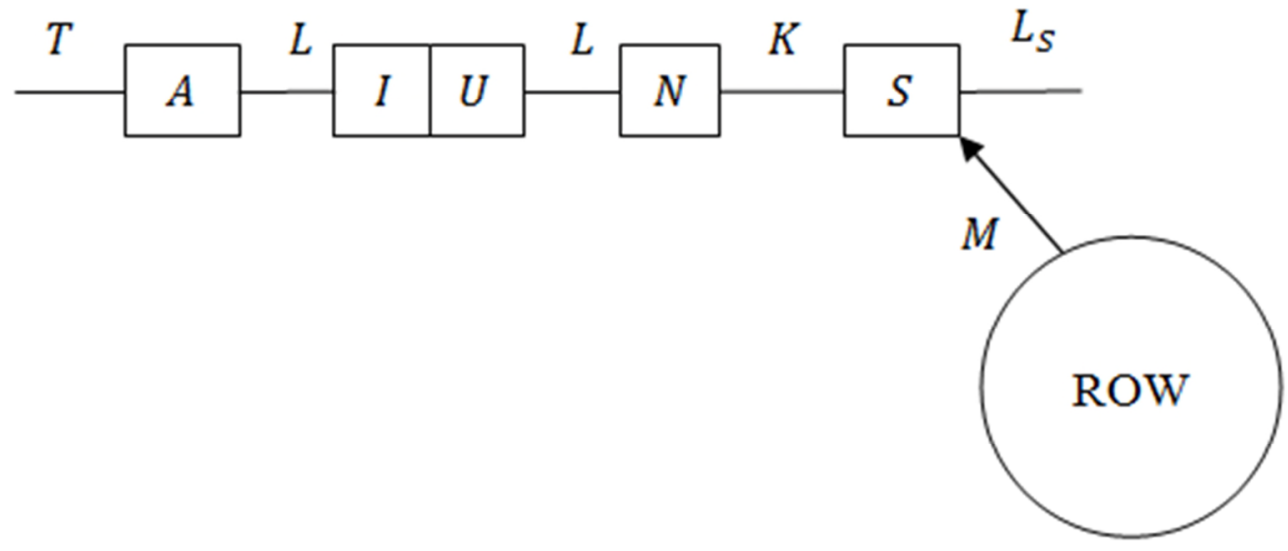

Similar to Marjit and Acharyya (2000, 2003), this model also makes a simplifying assumption that a non-traded final good is produced in the urban area using only unskilled labour in a fixed proportion. We assume that this non-traded good is produced in the formal sector where unskilled labour is hired at a contracted nominal wage, as considered in Marjit and Acharyya (2000, 2003). Unskilled labourers in the unorganised labour market of the rural agricultural sector get competitive (market-determined) money wages at the rate $W$, while their counterparts working in the organised labour markets of the formal sectors receive contractual money wages at the rate $W^{*}$, determined owing to prior unionised negotiation ${ }^{7}$, with $W<W^{*}$. Therefore, only the agricultural sector is modelled as the informal sector $^{8}$ where the unskilled labour gets a lower market-determined nominal wage. The skilled workers receive wages at the rate $W_{S}$. The rental to land-capital is denoted as $R$ and the interest rate on capital is denoted as $r$. The price the non-traded intermediate input $I, P_{I}$, is determined domestically by demand-supply mechanism. However, the price of non-traded final commodity $N, P_{N}$, is determined in this case by the labour cost given $W^{*}$ and therefore the production of the nontraded good $N$ is determined by the domestic demand for $N . a_{j i}$ denotes the amount of the $j^{\text {th }}$ input used in per-unit production of the $i^{\text {th }}$ good. $P_{i}^{*}$ denotes the internationally given price of the $i^{\text {th }}$ commodity owing to the small, open

\footnotetext{
${ }^{7}$ We assume the organised sector wages are institutionally given and we do not explicitly model the wage-bargaining here. For a discussion on how unionised wages are determined through collective bargaining, see Chaudhuri and Mukhopadhyay (2010), Mukherjee (2014) and so on.

${ }^{8}$ See footnote 1 in this context.
} 
economy assumption $(i=A, U, S)$. All markets, except the organised labour markets for the unskilled workers working in the formal sectors, are perfectly competitive. All production is subject to constant returns to scale. Except for the non-traded production and production in the input tier, there are diminishing returns to the variable factors in each sector. The price-unit cost equality conditions (the so-called 'zero-profit conditions') for the competitive producers are mentioned below.

$$
\begin{aligned}
& W a_{L A}+R a_{T A}=P_{A}^{*} \\
& W^{*} a_{L I}+r a_{K I}=P_{I} \\
& W^{*} a_{L U}+r a_{K U}+P_{I} a_{I U}=P_{U}^{*} \\
& W_{S} a_{S S}+r a_{K S}+P_{M}{ }^{*}(1+t) a_{M S}=P_{S}{ }^{*} \\
& W^{*} a_{L N}=P_{N}
\end{aligned}
$$

We assume that the per-unit requirement of the non-traded intermediate input in the production of sector $U\left(a_{I U}\right)$ and per-unit requirement of the imported input in sector $S\left(a_{M S}\right)$ are constant. Although these two assumptions are simplified assumptions, they are not without any basis. If we think of sector $U$ as an automobile industry that always uses four tyres as the intermediate input to build one car and sector $S$ as a software industry that always has a fixed requirement of automatic data processing machine or computer data storage units in the production process, then these assumptions are perfectly legitimate.

Full-employment in the factor market suggests

$$
\begin{aligned}
& a_{T A} A=\bar{T} \\
& a_{K I} I+a_{K U} U+a_{K S} S=\bar{K} \\
& a_{S S} S=\overline{L_{S}}
\end{aligned}
$$

Domestic demand-supply equality condition in the market for non-traded intermediate input implies 


$$
a_{I U} U=I
$$

Or,

$$
\widehat{U}=\hat{I}
$$

Where the ${ }^{\wedge}$ indicates proportional change. The unskilled labour-endowment equation is

$$
a_{L A} A+a_{L U} U+a_{L I} I+a_{L N} N=\bar{L}
$$

Following Marjit and Acharyya (2003) and Marjit et al. (2011) let us make a simplifying assumption that $\alpha$-proportion of the total urban income is spent on the non-traded good $N$. Thus, the domestic market clearing of non-traded good (assuming rural population cannot avail of $N$ )

$$
\alpha\left(P_{U}^{*} U+P_{S}^{*} S\right)=(1-\alpha) P_{N} N
$$

Once the domestic market for $N$ is cleared the overall trade is balanced.

The above equation system consists of eleven unknowns or endogenous variables of the system $\left(W, W_{S}, R, r, P_{I}, P_{N}, A, U, S, I, N\right)$ and eleven equations. The input-coefficients, $a_{j i}$ s, except the per-unit requirements of the imported and non-traded intermediate inputs $\left(a_{I U}\right.$ and $\left.a_{M S}\right)$ and the unit labour coefficient in the production of non-traded final $\operatorname{good} N\left(a_{L N}\right)$, are determined once the factor prices are known.

The model is solved as follows: Equations (2) and (3) simultaneously solve for $r$ and $P_{I}$ for exogenously given $W^{*}$ and $P_{U}^{*}$. Once $r$ is determined, zero-profit condition for the skilled labour-intensive manufacturing sector determines $W_{S}$ given $P_{S}^{*}, P_{M}^{*}$ and the ad-valorem rate of tariff imposed on the import of $M, t$. On the other hand, the price of the non-traded good is given by the labour cost, which is the product of fixed input-coefficient and the contracted unskilledwage, independent of the demand for non-traded good. Once the nominal skilled wage and the rate of return to capital are determined, total skilled labour force determines the skill-intensive manufacturing production and this together with the total domestic capital stock yields the production of the 
unskilled labour-intensive manufacturing good and consequently the production of the non-traded intermediate input, $I$, by dint of the complementarity in production process between these two sectors as given by Equation (9). The non-traded output, on the other hand, is demand-determined given the equilibrium values of $W_{S}, r$ and $U$ (and $I$ ), as evident from the market-clearing condition in Equation (11). Therefore, the formal sectors form an independent subsystem of the economy under consideration.

The output and prices of the factors used in production of $U, I, S$ and $N$ are all determined independent of the informal agricultural sector in this set-up. But the informal wage rate, the rental to land-capital and production in sector $A$ are determined once the equilibrium values in the formal sectors of the economy are obtained. In this set-up, the production activities in sector $A$ will be constrained by the outputs and hence by the demand for unskilled labour in the formal sectors. This depicts the importance of the non-traded good $N$. Because of the presence of the non-traded final good $N$, production of agricultural exports and the consequent demand for unskilled labour are constrained by the demand for $N$, which otherwise could have been satisfied through imports. Finally, given such an output level of the agricultural exports, informal competitive wage and the return to the specific factor, land-capital, must satisfy the zero-profit condition given by Equation (1) and full employment condition for land in Equation (6).

\subsubsection{Comparative Static Exercise - Tariff Reduction on Imported Intermediate Input ${ }^{9}$}

The key comparative static exercise in this paper is to consider a reduction in the ad valorem rate of tariff $(t)$ on the import of the intermediate input $M$.

Since interest rate on capital in the formal sector, $r$, is already determined by solving the zero-profit conditions given in Equations (2) and (3) simultaneously, $r$ does not change and hence skilled wage goes up as an immediate impact of the reduction in tariff on the imported input, as evident

${ }^{9}$ Detailed derivations of key algebraic expressions will be available upon request. 
from the zero-profit condition for the skill-intensive sector described in Equation (4). Therefore, denoting the proportional change by ' $\wedge$ ' (i.e. $\hat{X}=$ $d X / X)$, the expression for change in skilled wage is:

$$
\widehat{W_{S}}=-\left(\theta_{M S} T \hat{t} / \theta_{S S}\right)>0, \text { since } \hat{t}<0
$$

Where $\theta_{j i}$ denotes cost-share of the $j^{\text {th }}$ input in the production of the $i^{\text {th }}$ good (for example, $\theta_{S S}=\left(W_{S} a_{S S} / P_{S}^{*}\right)$ ) and $T=t /(1+t)$.

How does $W$ change? The agricultural sector with an informal labour market employs only those unskilled labourers that are not employed in the formal sectors of the economy (that is not employed in sectors $U$ and $N$ ). Therefore, it is obvious that production activities in the agricultural sector $(A)$ will be constrained by the demand for unskilled labour in the formal sectors and hence by the outputs in the formal sectors. So the effect on $W$ depends on whether the organised sectors using unskilled labour contracts or not.

Figure 2: Role of Non-traded Good

\begin{tabular}{|c|c|c|}
\hline \multicolumn{3}{|c|}{ Production of agricultural exports } \\
\hline & 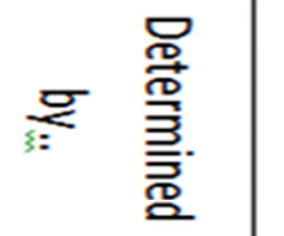 & \\
\hline \multicolumn{3}{|c|}{$\begin{array}{l}\text { Unskilled workers not receiving } \\
W^{*} \text { respond to the demand for } \\
\text { labour by A }\end{array}$} \\
\hline & 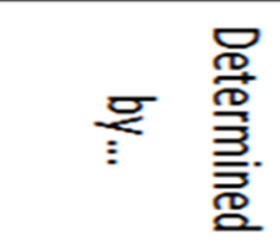 & \\
\hline $\begin{array}{c}\text { Demand \& suppl } \\
\text { formal sectors (i } \\
\text { non-traded secto } \\
\text { framework) }\end{array}$ & $\begin{array}{l}\text { Y conditio } \\
\text { nclusive o } \\
\text { ras well i } \\
\text { paying } W\end{array}$ & $\begin{array}{l}\text { is in } \\
\text { the } \\
\text { this }\end{array}$ \\
\hline
\end{tabular}


In algebraic terms,

$$
\frac{\sigma_{A} \lambda_{L A}}{\theta_{T A}} \widehat{W}=\left(1-\lambda_{L A}-\lambda_{L N}\right) \widehat{U}+\lambda_{L N} \widehat{N}
$$

Where $\lambda_{j i}$ denotes share of the $j^{\text {th }}$ input in the production of the $i^{\text {th }} \operatorname{good}$ (for example, $\left.\lambda_{L A}=\left(A a_{L A} / \bar{L}\right)\right)$. LHS measures change in labour demand in sector $A$ due to input substitution effect in sector $A$, but induced by change in $W$, which in turn, depends on how demand for unskilled labour by the rest of the economy changes; or in other words, how productions of $U$ (consequent upon change in $I$ ) and $N$ change. However, as sector $S$ expands, producers in sector $S$ demand more capital that must come from the vertically integrated sectors $U$ and $I$, leading to contraction of both sectors.

$$
\widehat{U}=\hat{I}=\left[\sigma_{S} \lambda_{K S} / \theta_{S S}\left(1-\lambda_{K S}\right)\right] \theta_{M S} T \hat{t}<0
$$

Hence, $\left(1-\lambda_{L A}-\lambda_{L N}\right) \widehat{U}<0$ implying fall in labour demand due to contraction of $U$ and $I$. Therefore, the changes in urban income and consequently the demand for the non-tradable can be in either direction. $W$ falls unequivocally only if $N$ contracts. Here lies the significance of the role of non-tradables. When the non-tradable is produced under contractual wages, the variation in demand for non-tradables only affects the production of nontradables.

Totally differentiating domestic market-clearing condition for the non-traded good and simplifying

$$
\widehat{N}=\mu \widehat{U}-\theta_{M S} T \hat{t} \frac{\sigma_{S}(1-\mu) \theta_{K S}}{\theta_{S S}}
$$

Where $\mu=\left\{\alpha P_{U}^{*} U /(1-\alpha) P_{N} N\right\}$ and $(1-\mu)=\left\{\alpha P_{S}^{*} S /(1-\alpha) P_{N} N\right\}$. It intuitively follows that higher (lower) value of $\mu$ means people in the urban areas earning from sector $U$ (sector $S$ ) spend relatively more on the good $N$. Equation (14) suggests direction of change in the demand for non-traded good and consequently on its production is ambiguous. The ambiguity stems from two alternative forces: one is increased demand by the skilled workers due to rise in their real earnings, another is reduced demand by the unskilled 
workforce in the urban area due to reduction in their real income owing to contraction of sector $U$.

Figure 3 quantifies in the two panels respectively the changes in the production of non-tradable $N$ and the consequent movement in informal wage for different values of $\sigma_{S}$ (the elasticity of substitution between skilled labour and capital in the skill-intensive sector $S$ ) in two different scenarios: $\mu=0.3$ and $\mu=0.7$, owing to a reduction in tariff on the imported input by 24 percentage points (as estimated by Goldberg et al., 2010 during 1989-1997 in India). ${ }^{10}$ When skilled wage increases owing to a tariff cut of $24 \%$ on the import of input $M$, with increase in the elasticity of substitution between skilled labour and capital, producers in sector $S$ would be more tempted to substitute capital for skilled labour and sector $S$ would expand even more and consequent contractionary impact on the vertically integrated sector $U$ would be higher as well since additional units of capital sector $S$ demands must come from sectors $I$ and $U$, thereby both direct and indirect capital usage by sector $U$ would decline at higher rate. Therefore income from sector $S$ (sector $U$ ) increases (decreases) at an increasing rate with increase in $\sigma_{S}$.

When $\mu=0.3$, we have the scenario when urban population earning from sector $S$ would spend relatively larger share of their income on the nontradable, $N$, compared to the urban population earning from the vertically integrated sector $U$. Sector $S$ expands more with the increase in $\sigma_{S}$; when the share of urban income from sector $S$ spent on the non-tradable $N$ is relatively higher, the decrease in the demand for $N$ by the urban people earning from the vertically integrated sector $U$ would be outweighed by the increase in demand for $N$ by the people receiving income from sector $S$ and consequently we observe a modest increase in the production of sector $N$ with increase in $\sigma_{S}$ for $\mu=0.3$. Therefore, for $\mu=0.3$, there would be two forces operating on the demand for unskilled workers in the formal sectors and consequently on the informal wage: one is decrease in demand for the unskilled workers at a higher rate by sector $U$ with the increase in $\sigma_{S}$ and another is the increased demand by

${ }^{10}$ The benchmark parameter values used for the sensitivity analysis are presented in Table A1.1 in Appendix I. 
the non-traded sector $N$, which is however, modest. Therefore, demand for unskilled workers in the formal sectors is not increased as a net effect and informal wage would decline, but the rate of decrease in informal wage is quite modest.

However, when $\mu=0.7$, share of urban income from the vertically integrated sector $U$ spent on $N$ is much higher compared to the people earning from sector $S$. So the contractionary impact on the vertically integrated sector $U$ would now be much more pronounced in determining the demand for $N$ by the urban population with the increase in $\sigma_{S}$. Therefore, demand for non-tradable $N$ would now decline as a net effect with the increase in $\sigma_{S}$. Consequently, demand for unskilled workers in the formal sectors would unambiguously fall and the informal wage would fall at a much higher rate compared to the case with $\mu=0.3$.

Figure 3: Movements in Non-traded Production $(N) \&$ Informal Wage $(W)$ following $24 \%$ Tariff-cut on Imports of $M$, for Different $\sigma_{S}$ at $\mu=0.3 \& \mu=0.7$, under Contractual Wage in Sector $N$
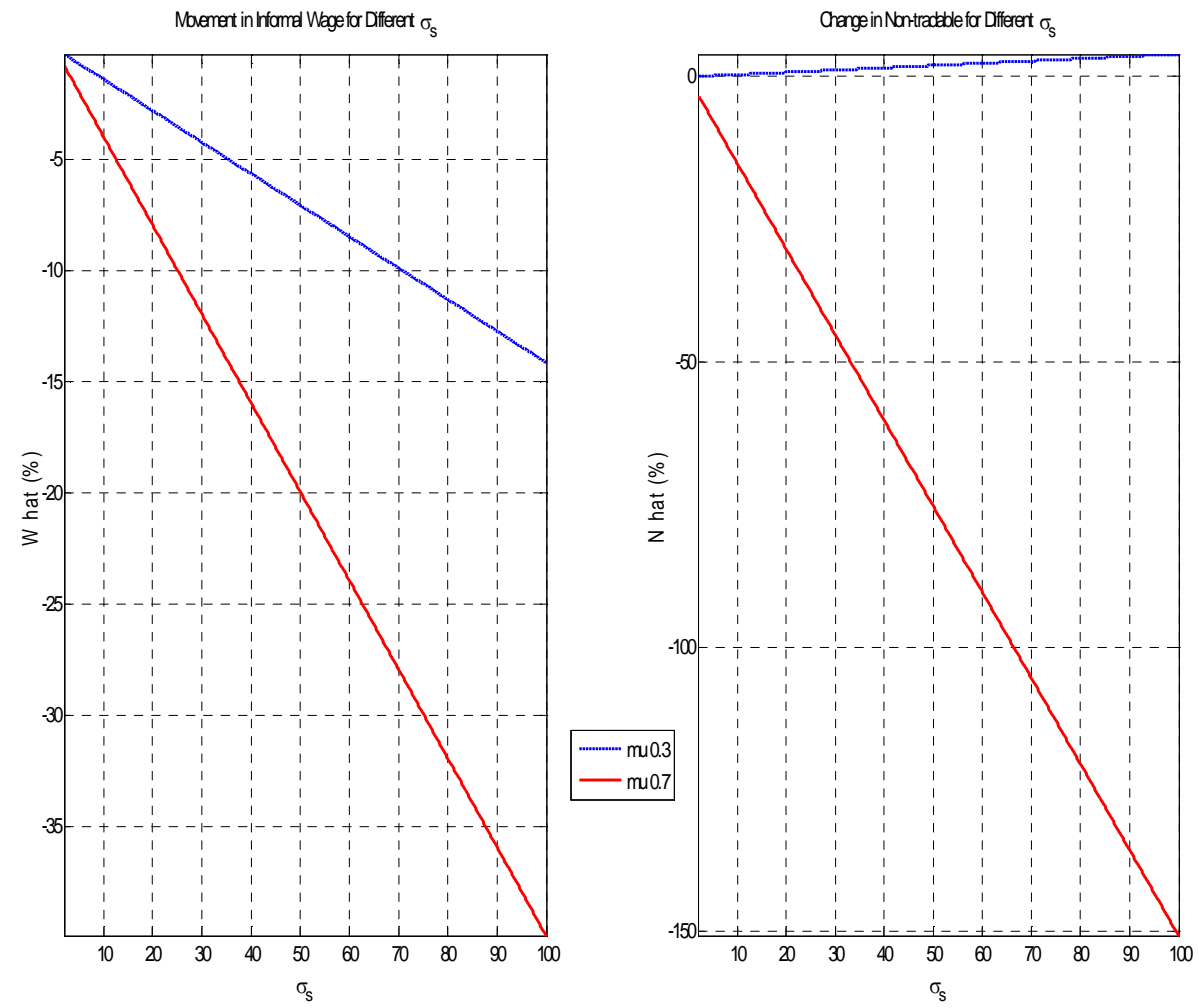
Totally differentiating the full-employment condition in the unskilled labour market and substituting values we obtain

$$
\widehat{L_{A}}=\hat{a}_{L A}+\hat{A}=-\frac{\sigma_{A}}{\theta_{T A}} \widehat{W}
$$

Since informal unskilled wage falls, total employment of unskilled workers in sector $A$ rises in this scenario with unionised wage in sector $N$. This is because, the reduction in flexible unskilled wage does not have any impact on determining the production in sector $N$ (due to the unionised unskilled labour market in sector $N$ ) and thus all the retrenched workers from sectors $U, I$ and $N$ will now be joining sector $A$.

\subsection{Non-traded Production in Unorganised Informal Sector}

In case of contractual wages in the formal non-traded sector $N$, non-traded price was held fixed by the unionised unskilled money wage. But in case of non-traded good being produced in the informal sector with unorganised labour market where unskilled labour receives market-determined (flexible) nominal wage, production of $N$ is no longer demand-determined. Consequently, $P_{N}$ is not just cost-determined. We continue to assume $a_{L N}$ is fixed (simplifying assumption). Therefore, the zero-profit condition for sector $N$ in Equation (5) can now be re-written as

$$
W a_{L N}=P_{N}
$$

The prices and output levels in the formal sectors $(U, I, S)$ can still be determined independent of the informal sectors $(A, N)$. The remaining variables can be determined as follows. For a given $P_{N}$, Equation (5.1) determines the unskilled wage, $W$, which then solves for the return to landcapital, $R$, from the zero-profit condition in Equation (1). Given these values of $W, R$ and the consequent input choices, the output levels of the agricultural 
exports $(A)$ and non-tradable $N$, are determined from Equations (6) and (10) respectively. This yields a supply curve for the non-tradable, $N$ as $N^{S}=$ $S\left(P_{N}\right)$. An increase in $P_{N}$ raises $W$ and lowers $R$. The subsequent increase in intensity of land-capital usage lowers the agricultural output, which, along with the less intensive use of unskilled labour due to the higher unskilled-wage, releases some unskilled labour; accordingly the non-traded output increases. We, therefore, have a positive association between $P_{N}$ and $N^{S}$. So the supply curve is positively sloped.

On the other hand, the demand relationship for the non-traded good $N$ in Equation (11) now becomes a rectangular hyperbola in this case.

\section{Figure 4: Equilibrium in the Market for $N$}

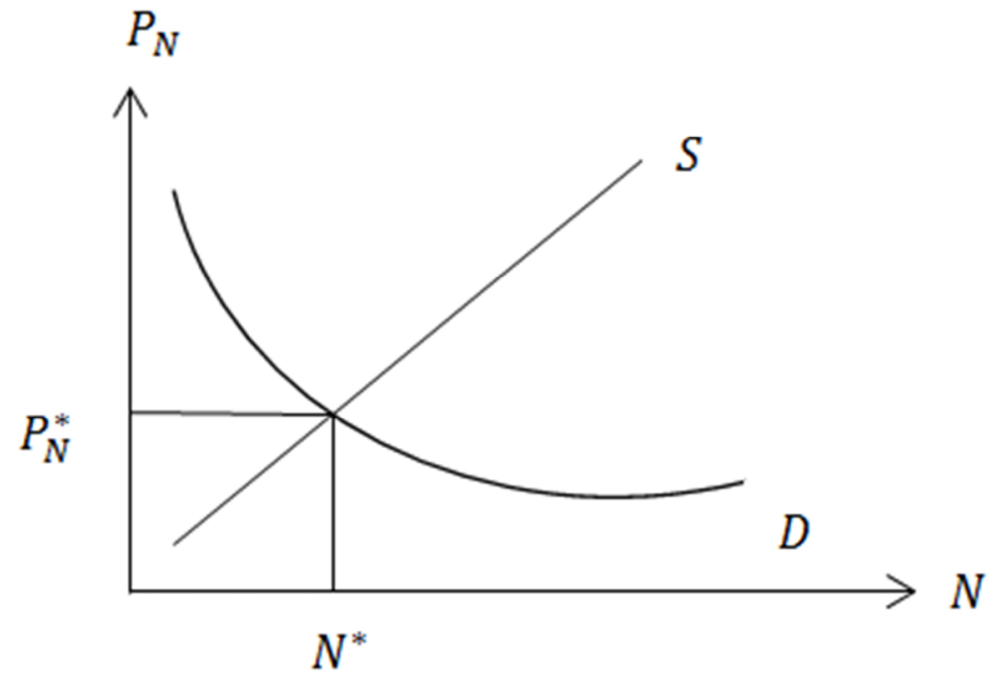

\subsubsection{Comparative Static Exercise - Decline in Tariff on Imports of $M$ under Flexible Wage Production in Non-traded Sector}

This interaction of demand for and supply of non-tradable $N$ in determining its price and output levels has important implications on the wage-gap between skilled and unskilled labour. Given (5.1), i.e., proportionality between $P_{N}$ and $W$, it is immediate that whether the wage-gap widens or declines following tariff cut on imports of $M$ depends crucially on the movement of $P_{N}$. In the 
earlier case of the production of $N$ with contractual unskilled money wage, it was only the demand-determined production of $N$, which was crucial. But now with the price of $N$ no longer determined by the contracted unskilled nominal wage, supply of $N$ is of no less importance in determining the movement in unskilled-wage.

Equation (15) now changes to

$$
\theta_{L N} \widehat{W}+\widehat{N}=\mu \widehat{U}-\theta_{M S} T \hat{t} \frac{\sigma_{S}(1-\mu) \theta_{K S}}{\theta_{S S}}
$$

Therefore, when non-tradable is produced in the unorganised informal sector, we can get expression for $\widehat{W}$ under tariff reduction on the imported input $M$ by solving Equations (13), (14) and (15.1) simultaneously.

From Equation (15.1) it can be inferred that given supply, the demand for nontradable $N$ is ambiguous for the same reason mentioned before while discussing Equation (15). Therefore, the price of the non-traded good now may move in either direction. On the other hand, the supply effect depresses the non-traded price: At the initial $P_{N}$ and hence at the initial $W$ and $A$, unskilled labour released from the contracting sectors $U$ and $I$ relaxes the (net) labour constraint for the non-traded sector and thereby raises its supply. This additional supply effect imposes a downward pressure on unskilled wage and therefore reduces $P_{N}$. Figure 5 demonstrates the possibility where both demand for and supply of non-traded good increase but since supply increases by more than the increase in demand, price of the non-tradable falls from $P_{N}^{1}$ to $P_{N}^{2}$ while production of non-tradable rises from $N_{1}$ to $N_{2}$. 

Figure 5: Comparative Static Response in the Domestic Market for
$N$ under Flexible Unskilled Wage

$P_{N}$

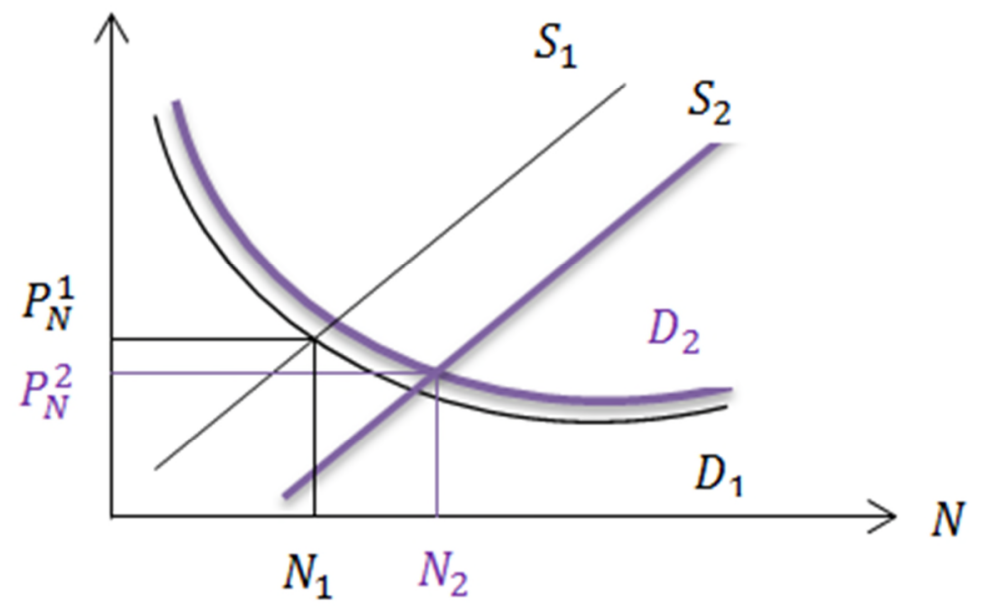

Figure 6 represents similar kind of sensitivity analysis as performed in Figure 2 , however now under the assumption of flexible unskilled wage in the nontradable sector. When $\mu=0.3$, share of total urban income from sector $S$ spent on non-traded good $N$ is relatively high and hence there is a net increase in the demand for $N$ (since sector $S$ expands at the expense of sector $U$ ) at initial $P_{N}$. However, the increases in the supply of unskilled labour to sectors $A$ and $N$ depress $W$ and therefore price of non-tradable. This yields the same scenario as the one depicted in Figure 5. Hence, as $\sigma_{S}$ rises, expansion of sector $S$ and consequent contraction of sectors $U$ and $I$ induce increase in non-traded production by dint of higher supply of unskilled labour, but reduction in $W$.

However, when $\mu=0.7$, share of urban income from the contracting vertically integrated sector $U$ spent on non-tradable is relatively higher. Therefore, there is a net decline in the demand for and supply of non-tradable at initial $P_{N}$. But this dominant supply effect leads to an increase in $P_{N}$ (supply curve shifts upwards by more than the downward shift in demand curve, as shown in Figure 7 below). Given the proportional relationship between competitive unskilled wage and $P_{N}$, as laid in Equation (5.1), this latter effect outweighs the former impact on $W$ and we observe a net increase in $W$ but a decline in non-traded production in Figure 3 for $\mu=0.7$. 
Figure 6: Movements in Non-traded Production $(N)$ \& Informal Wage $(W)$ following $24 \%$ Tariff-cut on Imports of $M$, for Different $\sigma_{S}$ at $\mu=0.3$ $\& \mu=0.7$, under Flexible Wage in Sector $N$
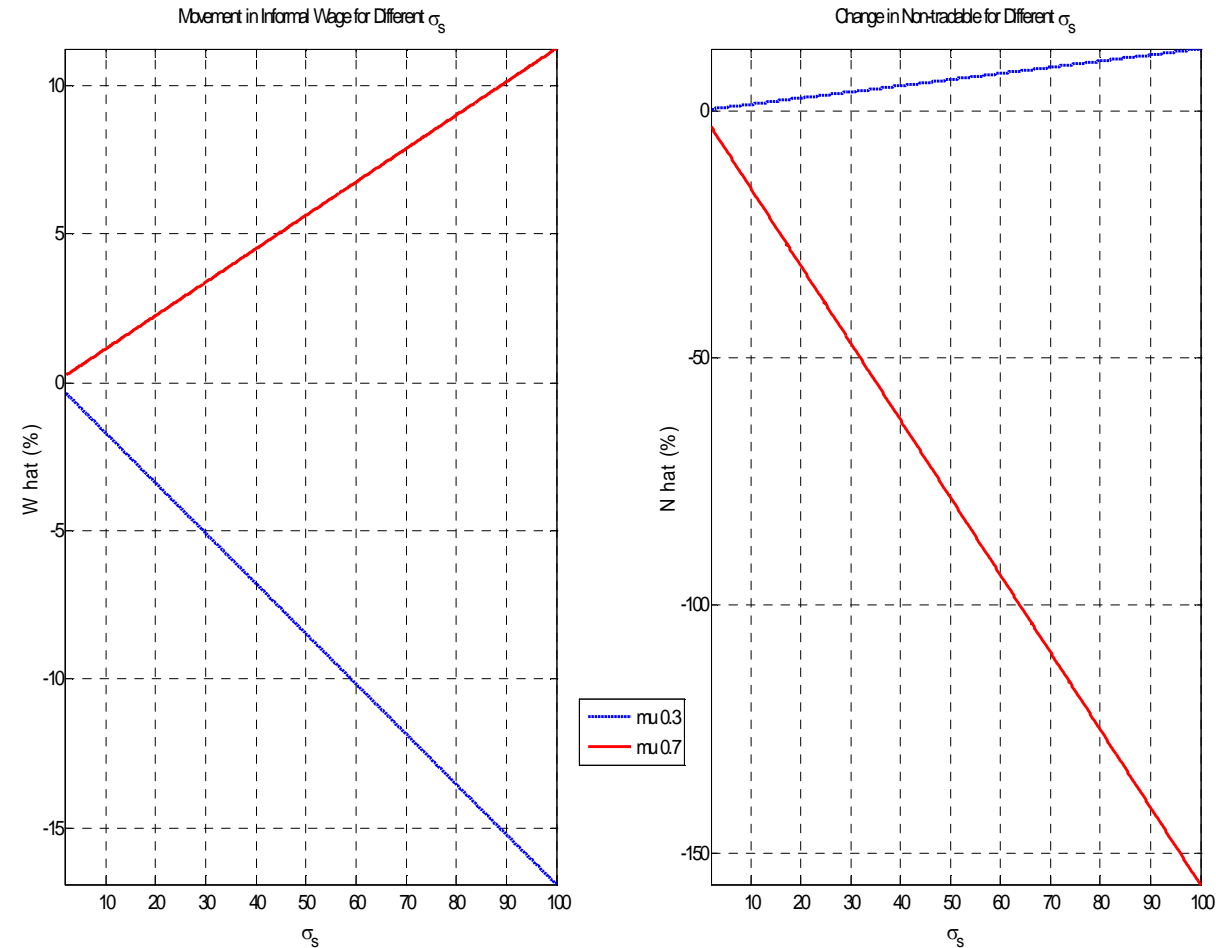

Figure 7: Comparative Static Response in the Domestic Market for $\boldsymbol{N}$ under Flexible Unskilled Wage with $\boldsymbol{\mu}=\mathbf{0 . 7}$

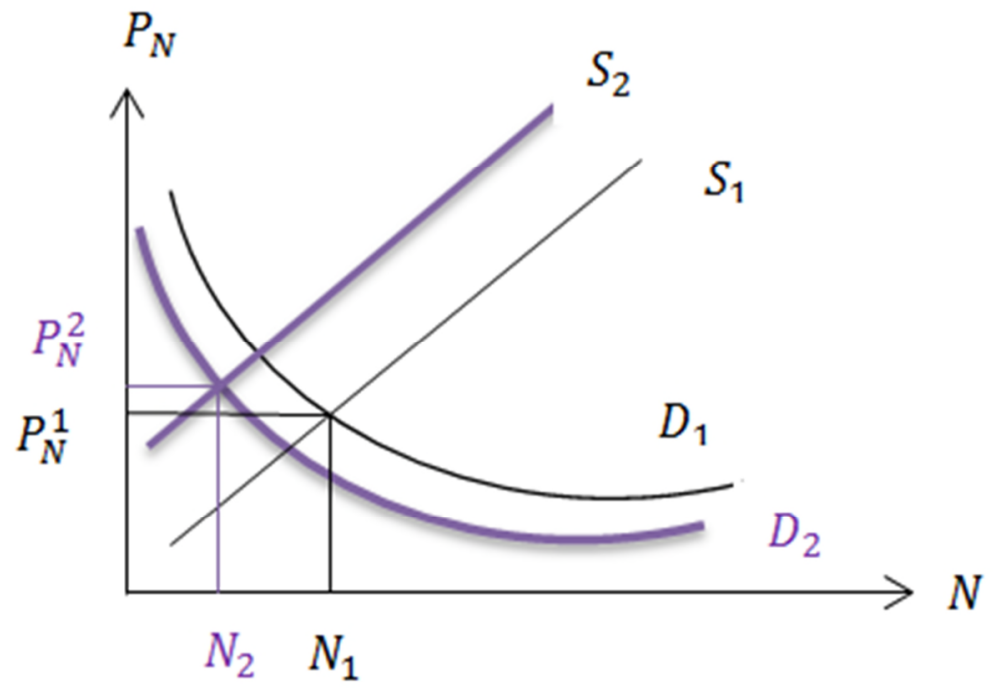

Another interesting exercise has been tracing out the movements of production of $N$ and resulting movement of $W$ under flexible wage in the non-traded sector owing to a $24 \%$ tariff reduction on the imports of $M$ by changing $\sigma_{A}$, the 
elasticity of substitution between unskilled labour and land-capital in the agricultural sector, from 0.6 to 3 . This analysis has been motivated by an interesting observation in Golder et al. (2014) who have reported that $\sigma_{A}$ can either be less than (but closer to) or more than unity, with preferred estimated value as 1.2 (obtained by direct estimation of CES production function using non-linear least squares approach) that has been taken as the benchmark value in the earlier analyses for varying $\sigma_{S}$. For the sake of brevity this paper only examines this under flexible $W$ assumption in sector $N$, since that renders seemingly counter-intuitive results.

Although the retrenched unskilled workers from sectors $U$ and $I$ flow to sectors $A$ and $N$, when $\mu=0.3$, producers in sectors $N$ demand more of the unskilled workers. This will raise the demand for unskilled workers in sector $N$, imposing an upward pressure on informal wage $(\widehat{W}$ starts becoming less negative in Figure 8). Given Equation (5.1), this leads to an increase in nontraded price and subsequent reduction in the supply of $N$. This additional supply effect induces sector $N$ to release some unskilled labour to sector $A$. For low values of $\sigma_{A}$, even with the increase in $W$ producers in sector $A$ would be relatively less willing to substitute unskilled labour by land-capital and continue to demand unskilled labour for the expansion of sector $A$. Thus, $W$ continues to go up for low values of $\sigma_{A}$, but after a certain level, for relatively higher values of $\sigma_{A}$, producers in sector $A$ substitute land-capital for relatively costlier unskilled labour that imposes a downward pull on $W$ and consequently on $P_{N}$. These retrenched unskilled workers from sector $A$ will now migrate to sector $N$ and that exerts an upward push on non-traded production. Therefore, the resultant trajectory of $\widehat{N}$ takes a convex (to the origin) pattern while that of $\widehat{W}$ takes a concave (from the origin) pattern from lower to higher values of $\sigma_{A}$ for $\mu=0.3$.

For $\mu=0.7$, demand for $N$ falls by the urban consumers as a net effect whereas retrenchment of unskilled workers from sectors $U$ and $I$ leads to an excess supply of unskilled labour in the competitive unskilled labour market of sector $N$ and thereby reducing $W$. However, with the increase in $\sigma_{A}$, producers in sector $A$ are going to substitute land-capital by labour in production that 
imposes a consequent upward pressure on $W$, which, in turn, would increase $P_{N}$, implying a subsequent reduction in supply of $N$. Therefore, we observe exactly mirror images to those for $\mu=0.3$ in the trajectories of $\widehat{N}$ and $\widehat{W}$ (i.e. concave from the origin for $\widehat{N}$ and convex to the origin for $\widehat{W}$ ) from lower to higher values of $\sigma_{A}$ for $\mu=0.7$.

Figure 8: Movements in Non-traded Production $(N) \&$ Informal Wage $(W)$ following $24 \%$ Tariff-cut on Imports of $M$, for Different $\sigma_{A}$ at $\mu=0.3$ $\& \mu=0.7$, under Flexible Wage in Sector $N$
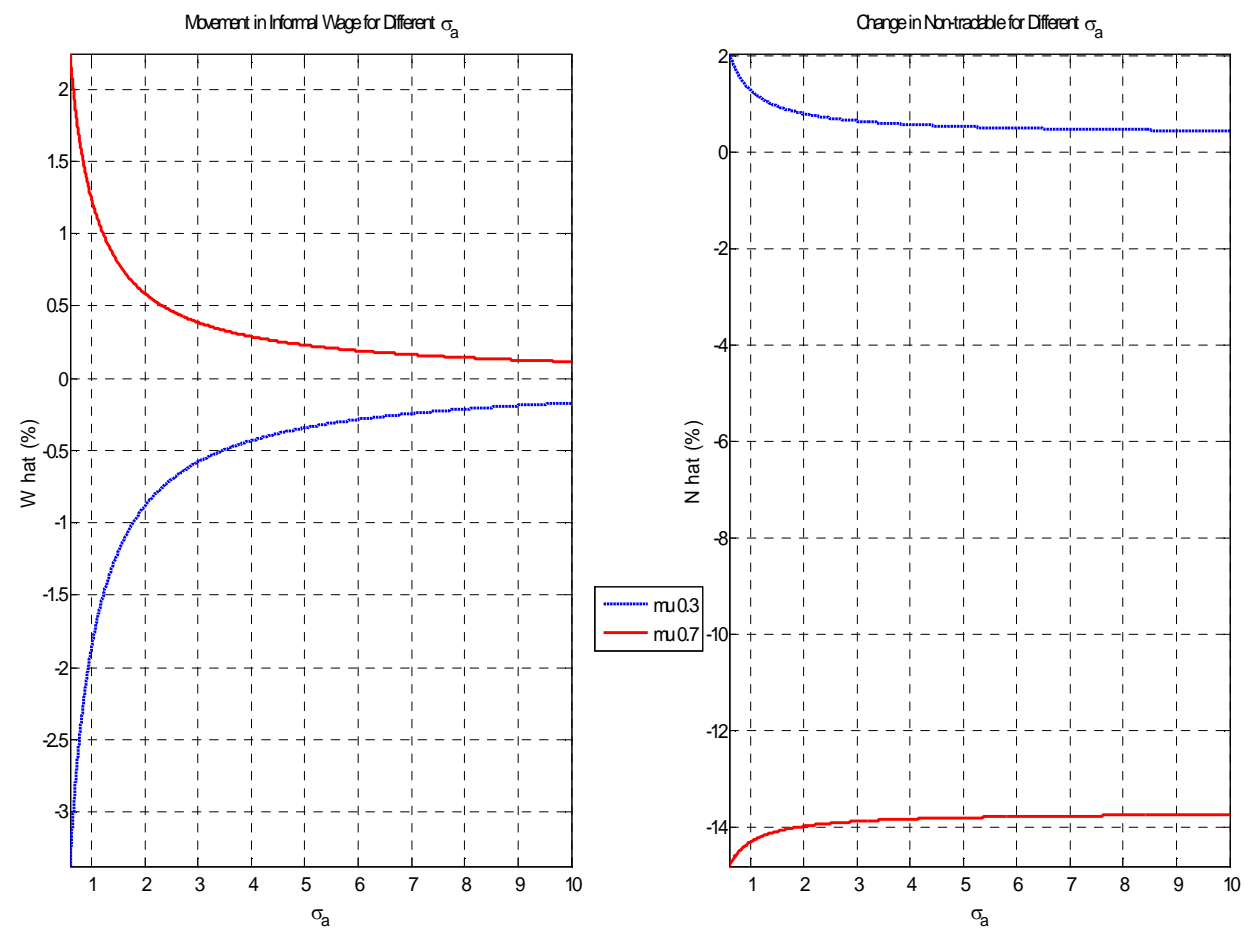

Employment of Unskilled Workers in the Informal Sector

Note that, now we have two sectors with 'informal' labour market: one is sector $A$ and another is sector $N$. The total employment of unskilled workers in the informal sectors is therefore, given by

$$
\widehat{L_{A}}+\widehat{L_{N}}=\left(\theta_{L N}-\frac{\sigma_{A}}{\theta_{T A}}\right) \widehat{W}
$$

Therefore, if unskilled labour and land-capital are less than perfect substitutes in sector $A$ (i.e. $\sigma_{A}<1$ ), informal employment changes in the same direction of change in $W$ if $\theta_{L N} \theta_{T A}>\sigma_{A}$. However, if $\sigma_{A}>1$, direction of change in 
informal employment would be opposite to that in $W$. This is because, when $W$ falls $P_{N}$ falls and that reduces demand for the non-tradable, which, in turn, affects non-traded production; while if $\sigma_{A}>1$, producers in sector $A$ would be quite willing to minimise production cost by substituting retrenched unskilled labour for capital and that can boost employment of unskilled workers in the informal labour market of sector $A$. However, for low values of $\sigma_{A}$ sector $A$ producers would also be unwilling to employ additional units of retrenched worker for capital. Therefore total employment in the informal sector will also fall in that case.

\subsection{Expression for Relative Wage-inequality}

Since the unskilled labourers are entitled to receive either the flexible wage in the informal unorganised sector or the fixed wage in the organised sector, we can define an average unskilled wage of the economy and can consequently define the ratio of skilled wage over the average unskilled wage of the economy as the expression for relative wage-gap in the economy under consideration.

\section{(a) Non-tradable Production under Contractual Wage}

With flexible wage in sector $A$ but unionised wage in sectors $U, I$ and $N$ the expression for the average unskilled wage in the economy becomes the weighted average of total money wage paid in respective sectors, when the weights are employment shares of respective sectors.

$$
\begin{gathered}
W_{A}=W \lambda_{L A}+W^{*}\left(\lambda_{L I}+\lambda_{L U}+\lambda_{L N}\right) \\
\text { Or, } W_{A}=W^{*}-\left(W^{*}-W\right) \lambda_{L A}
\end{gathered}
$$

Since $\sum_{i} \lambda_{L i}=1$, where $i=A, I, U, N$.

Therefore,

$$
d W_{A}=d W \lambda_{L A}-W d \lambda_{L A}
$$


Or,

$$
\widehat{W}_{A}=\left(W \lambda_{L A} / W_{A}\right) \widehat{W}-\left(W \lambda_{L A} / W_{A}\right)\left(\hat{a}_{L A}+\hat{A}\right)
$$

Since $\lambda_{L A}=\left(a_{L A} A / \bar{L}\right)$. Therefore,

$\widehat{W}_{A}=\left(W \lambda_{L A} / W_{A}\right)\left(1+\frac{\sigma_{A}}{\theta_{T A}}\right) \widehat{W}$

Therefore, $\widehat{W}_{A}<0$ if $W$ falls owing to tariff-cut on the imports of $M$.

\section{(b) Non-tradable Production in the Informal Sector with Flexible Wages}

Just like (a), it can be shown that

$\widehat{W_{A}}=\left(W / W_{A}\right) \widehat{W}\left(\lambda_{L A}+\lambda_{L N}\right)+\left\{\left(W^{*}-W\right) / W_{A}\right\}\left(1-\lambda_{L A}-\lambda_{L N}\right) \widehat{U}$

Since $\widehat{U}<0, \widehat{W}_{A}<0$ if $W$ falls as a consequence of tariff reduction on the imports of $M$.

Therefore, the expression for wage-inequality in both (a) and (b) would be

$$
\Omega=W_{S} / W_{A}
$$

Or,

$\widehat{\Omega}=\widehat{W}_{S}-\widehat{W}_{A}$

Wherein an increase (decrease) in $\Omega$ means a deterioration (improvement) in wage-inequality. As evident from the above discussions, the degree of substitutability between skilled labour and capital is of utmost importance to determine the fate of sector $N$ and the consequent implication for the unskilled informal wage. Therefore, let us summarise the implications of liberalisation of input trade and the consequent demand-driven rise in skill-premium on the relative wage-inequality for different $\sigma_{S}$ in the following table, on the basis of the observations from Figure 3 and Figure 5: 
Table 1: Tariff-cut on Imports of $M$ and Directions of Relative Wageinequality for Rising $\sigma_{S}$

\begin{tabular}{ccc} 
& $\begin{array}{c}\text { Case I (Unionised } \\
\text { Unskilled Wage in } \\
\text { Sector } N \text { ) }\end{array}$ & $\begin{array}{c}\text { Case II (Flexible } \\
\text { Unskilled Wage in } \\
\text { Sector } N \text { ) }\end{array}$ \\
\cline { 2 - 3 } & $\widehat{\Omega}>0$ & $\widehat{\Omega}>0$ and getting \\
& magnified $\sigma_{S}$ rises \\
$\mu=0.7$ & $\widehat{\Omega}>0$ and getting \\
magnified & $\widehat{\Omega}>0$ or $<0, \widehat{\Omega}$ gets \\
smaller even if $>0$
\end{tabular}

\section{Concluding Remarks}

Growth acceleration in skill-intensive sectors has been one of the most prominent features of the liberalisation experience in India. On the other hand, liberalisation has facilitated import of capital goods and thus skill-intensive foreign technology that leads to increased demand for skilled workforce driving their wages up. This paper explores the general equilibrium impact of such trade-induced growth in the skill-intensive sector on informal sector wages and employment and most importantly, how this impact is mediated through the existence of finished non-tradable and the corresponding domestic demand-supply forces. This paper re-establishes the claim put forward by Marjit and Acharyya (2003) that the organisation of production of the nontraded final good is indeed important - in particular, whether the production cost of the non-tradable is market determined or not. The numerical analysis explores this point further, with varying elasticities of factor substitution in skill-intensive and agricultural production respectively. Therefore, this paper challenges the view that the relative wage-inequality in a DC like India with 
rigid organised sector labour market has unequivocally been governed only by the increase in the skilled wages. The sector-level general equilibrium approach adopted in this paper has not only been able to enlighten the role of various degrees of factor substitutability in production organised in different sectors, but also to highlight the role of non-traded consumption goods in determining the supply of unskilled labour to the informal (unorganised) sector and consequently the implication on competitive unskilled wage and subsequently, the direction of the relative wage-gap. Therefore, the relationships and results are indeed important to formulate policies aiming at betterment of the position of the unskilled poor workers. However one future extension of this exercise could be introducing skill-formation and capitaladjustment costs into the basic full-employment static general equilibrium model under consideration. ${ }^{11}$

\section{Appendix I}

Table A1.1: Parameter Values for Sensitivity Analyses

Parameters

$\theta_{L N}$

Cost-share of labour in sector $N$

$\theta_{L A} \quad$ Cost-share of labour in sector $A$

$\theta_{T A} \quad$ Cost-share of land-capital in sector $A$

$\theta_{S S} \quad$ Cost-share of skilled-labour in sector $S$

$\theta_{M S} \quad$ Cost-share of imported input in sector $S$

$\theta_{K S} \quad$ Cost-share of capital in sector $S$

$\lambda_{K S} \quad$ Share of capital used in sector $S$

$\lambda_{L N} \quad$ Share of unskilled labour employed in sector

\section{Values}

0.5

0.6

$0.4=\left(1-\theta_{L A}\right)$

0.6

0.1 (constant)

0.3

0.4

0.3

\footnotetext{
${ }^{11}$ This is now work in progress.
} 


\begin{tabular}{|c|c|c|}
\hline & $N$ & \\
\hline$\lambda_{L A}$ & $\begin{array}{l}\text { Share of unskilled labour employed in sector } \\
A\end{array}$ & 0.5 \\
\hline$\sigma_{S}$ & $\begin{array}{l}\text { Elasticity of substitution between skilled } \\
\text { labour and capital in sector } S\end{array}$ & {$[1.5,3.7,100]$} \\
\hline$\sigma_{A}$ & $\begin{array}{l}\text { Elasticity of substitution between labour and } \\
\text { land-capital in sector } A\end{array}$ & {$[0.6,1.2,3]$} \\
\hline
\end{tabular}

Source: Abraham 2010, Berman et al. 2005, Marjit and Kar 2008, Marjit et al. 2011, Seker \& RodriguezDelgado (2011), Broda et al. (2006) (for the ranges of $\sigma_{S}$ ) and Golder et al. (2014) (for ranges of $\sigma_{A}$ ).

\section{References}

Abraham, V. 2010. The effect of information technology on wage inequality: evidence from Indian manufacturing sector, CDS working papers, no.437, Trivandrum, CDS.

Acharyya, R. and Marjit, S. 2000. 'Globalisation and Inequality: An Analytical Perspective.' Economic and Political Weekly, Vol. 35, pp. 3503-3510.

Agenor, P.R. 1996. The Labor Market and Economic Adjustment. IMF Staff Papers 32, pp. $261-335$.

Alvarez, R. and Lopez, R. A. 2005. 'Exporting and performance: evidence from Chilean plants'. Canadian Journal of Economics/Revue canadienne d'économique, Vol. 38, pp. 1384-1400 .

Arora, S. and Chakraborty, A. 2004. 'Importing Jobs? The impact of global outsourcing on Wages in Indian Manufacturing.' Indian Journal of Economics and Business, Vol. 3, pp. 137-152.

Attansio, O., Goldberg, P. K. and Pavcnik, N. 2004. 'Trade reforms and wage inequality in Colombia.' Journal of Development Economics, Vol. 74, pp. 331-366. 
Berman, E., Somanathan, R. and Tan, H.W. 2005. Is Skill-biased Technological Change Here Yet? Evidence from Indian Manufacturing in the 1990s. World Bank Policy Research Working Paper 3761.

Besley, T. and Burgess, R. 2004. 'Can Labor Regulation Hinder Economic Performance? Evidence from India.' The Quarterly Journal of Economics, Vol. 119, pp. 91-134.

Broda, Christian, Joshua Greenfield, and David E. Weinstein 2006. From Groundnuts to Globalization: A Structural Estimate of Trade and Growth. NBER Working Paper No. w12512.

Chaudhuri, S. 2005. 'Labour Market Distortion, Technology Transfer and Gainful Effects of Foreign Capital', The Manchester School Vol. 73, No. 2, pp. 214-227.

Chaudhuri, S. 2007. 'Foreign capital, welfare and urban unemployment in the presence of agricultural dualism.' Japan and the World Economy, Vol. 19, pp. 149-165.

Chaudhuri, S. and Yabuuchi, S. 2008. 'Foreign capital and skilledunskilled wage inequality in a developing economy with nontraded goods.' In: S. Marjit and E. Yu (eds.) Contemporary and Emerging Issues in Trade Theory and Policy, Emerald Group Publishing Limited, UK.

Chaudhuri, S. and Mukhopadhyay, U. 2010. 'The Harris-Todaro Migration Model and Introduction of the Informal Sector.' In: Revisiting the Informal Sector. Springer, New York.

Das, G. G. 2012. 'Fragmentation in Production, Vertical Integration and Wage Inequality: A Theoretical Note'. Modern Economy Vol. 3, pp. 958-964.

Feenstra, R. C. and Gordon, H. H. 1996. 'Globalization, Outsourcing and Wage Inequality.' The American Economic Review, Vol. 86, pp. 240-245.

Goldberg, P., Khandelwal, A., Pavcnik, N. and Topalova, P. 2009. 'Trade Liberalization and New Imported Inputs.' American Economic Review, Vol. 99, pp. 494-500. 
Goldberg, P. K., Khandelwal, A. K., Pavcnik, N. and Topalova, P. 2010. 'Imported Intermediate Inputs and Domestic Product Growth: Evidence from India.' The Quarterly Journal of Economics, Vol. 125, pp. 1727-1767.

Gupta, M. R. and Dutta, P. B. 2011. 'Skilled-unskilled wage inequality and unemployment: A general equilibrium analysis.' Economic Modelling, Vol. 28, pp. 1977-1983.

Jones, R. and Kierzkowski, H. 2001. 'Horizontal Aspects of Vertical Fragmentation.' In: Cheng, L. and Kierzkowski, H. (eds.) Global Production and Trade in East Asia. Springer US.

Kumar, U. and Mishra, P. 2008. 'Trade Liberalization and Wage Inequality: Evidence from India.' Review of Development Economics, Vol. 12, pp. 291-311.

Lopez, R. A. 2015. 'Trade and firm performance'. In: Morrissey et al. (eds.) Handbook on Trade and Development, Edward Elgar Publishing Limited, United Kingdom.

Marjit, S. and Acharyya, R. 2003. International Trade, Wage Inequality and the Developing Economy: A General Equilibrium Approach. Physica-Verlag, Springer, Heidelberg.

Marjit, S., Kar, S. and R Acharyaa 2007. 'Agricultural Prospects and Informal Wage in General Equilibrium', Economic Modelling Vol. 24, No. 3, pp. 380-385.

Marjit, S., and Kar, S. 2008. 'Labor Productivity Growth, Informal Wage and Capital Mobility - A General Equilibrium Analysis', In: Ravi Kanbur and Jan Svejnar (Eds.) Labour Markets and Economic Development, NY: Routledge, 2008.

Marjit, S., Kar, S. and Chaudhuri, S. 2011. 'Recession in the skilled sector and implications for informal wage', Research in Economics Vol. 65, pp. 158-163.

Mukherjee, S. 2012. 'Revisiting the Apparent Paradox: Foreign Capital Inflow, Welfare Amelioration and 'Jobless Growth' with Agricultural Dualism and Non-traded Intermediate Input'. Journal of Economic Integration, Vol. 27, No. 1, pp. 12333. 
Mukherjee, S. 2014. 'Liberalisation and 'Jobless Growth' in Developing Economy - Some Extended Results'. Journal of Economic Integration, Vol. 29, No. 3, pp. 450-469.

Nagaraj, R. 2004. Labour market issues in India: A note. In: Fifth annual conference. Washington, DC: Global Development Network.

Robbins, D. J. 1996. Evidence on Trade and Wages in the Developing World, OECD Development Centre Working Papers, No. 119, OECD Publishing, Paris.

DOI: 〈http://dx.doi.org/10.1787/113347174747>.

Schady, N. and Sánchez-Páramo, C. 2003. Off and Running? Technology, Trade, and the Rising Demand for Skilled Workers in Latin America. World Bank Policy Research Working Paper No. 3015.

Seker, M., and Rodriguez-Delgado, J. D. 2011. Imported Intermediate Goods and Product Innovation: Evidence from India. Mimeo.

Sharma, K. and Morrissey, O. 2006. 'Trade, growth and inequality in the era of globalisation'. In: Sharma, K. and Morrissey, O. (eds.) Trade, Growth and Inequality in the Era of Globalisation, Routledge.

Topalova, P. 2010. 'Factor Immobility and Regional Impacts of Trade Liberalization: Evidence on Poverty from India.' American Economic Journal: Applied Economics, Vol. 2, pp. 1-41. 